\title{
Analisis Potensi dan Kelayakan Usahatani Sistem Integrasi Padi Ternak (Studi Kasus di Desa Silea Jaya Kecamatan Buke Kabupaten Konawe Selatan)
}

\author{
Samsul Alam Fyka ${ }^{*}$, Muhammad Aswar Limi ${ }^{1}$, Munirwan Zani ${ }^{1}$, Salamah ${ }^{2}$ \\ ${ }^{1 *}$ Dosen Agribisnis Fakultas Pertanian Universitas Halu Oleo \\ ${ }^{2}$ Alumni Agribisnis Fakultas Pertanian Universitas Halu Oleo \\ Kampus Hijau Bumi Tridharma, Jl. H.E.A. Mokodompit, Anduonohu, Kendari 93232 \\ *Email korespondensi: samsulalamfyka@gmail.com
}

(diterima: 04-07-2019; disetujui: 27-08-2019)

\begin{abstract}
ABSTRAK
Tujuan penelitian ini untuk mengetahui potensi sistem intergasi padi ternak (SIPT) melalui ketersediaan ouput padi dan ternak sapi potong dan mengetahui kelayakan usahatani SIPT di Desa Silea Jaya Kecamatan Buke Kabupaten Konawe Selatan. Responden penelitian ini berjumlah 25 orang, yaitu keseluruhan petani yang menerapkan sistem integrasi. Analisis data yang digunakan adalah analisis deskriptif kuantitatif dan kelayakan usaha SIPT dengan menggunakan dua pendekatan yaitu analisis Revenue Cost Ratio (R/C Ratio) dan Breack Even Point (BEP). Hasil penelitian menunjukkan bahwa potensi SIPT di Desa Silea Jaya cukup untuk mendukung pengembangan SIPT ini dengan melihat melalui potensi luas, lahan, kepemilikan ternak, limbah padi sawah dan sapi potong. Sedangkan untuk kelayakan usaha farming system di Desa Silea Jaya layak untuk dijalankan hal ini terlihat dari hasil analisis $R / C$ Ratio yaitu 5,26 (R/C Ratio $>1)$ dan analisis BEP untuk padi sawah yakni 1.150,41 kg dengan harga jual $\mathrm{Rp}$ 1.054,27. Sedangkan ternak sapi potong yakni 0,2 ekor dengan nilai Rp. 432.279 .
\end{abstract}

Kata kunci: kelayakan, potensi, sistem integrasi

\section{ABSTRACT}

The objective of this research is to know the potency of paddy-cattle integration system (SIPT) through the availability of rice output and beef cattle and to recognize the feasibility. The number of respondents in this study was 25 people, all of the farmers who implemented the integration system. The analysis applied in this study is quantitative descriptive analysis and feasibility of SIPT with two approaches, i.e. analysis of Revenue Cost Ratio (R/C Ratio) and Break Even Point (BEP). The result shows that the potential of SIPT in Silea Jaya Village is sufficient to support the development of this SIPT by noticing the vast potential, land, livestock ownership, rice paddy waste, and beef cattle. For the activity feasibility of the farming system in Silea Jaya Village, it is proper to run. It is concluded from the result of $\mathrm{R} / \mathrm{C}$ Ratio analysis which is 5,26 (R/C Ratio $>1$ ) and BEP analysis for paddy rice which is $1,150.41 \mathrm{~kg}$ with a selling price of IDR $1,054.27$, and beef cattle is 0.2 with a price of IDR 432,279.

Keyword: integrated farming system, feasibility, potency

\section{PENDAHULUAN}

Sistem integrasi padi ternak adalah suatu konsep pengembangan pertanian yang memandang usahatani sebagai suatu sistem. Dalam hal ini terdapat keterkaitan antar cabang usahatani, baik dalam penggunaan input maupun dalam tingkat output yang dihasilkan. Sistem integrasi padi-ternak (SIPT) merupakan salah satu model yang sering digunakan oleh petani, baik itu dalam bentuk masih sangat tradisional maupun yang sudah modern. Sistem ini mampu memanfaatkan sumber daya lokal dari usahatani padi sawah dan ternak sapi potong dalam bentuk kotoran sapi dan jerami serta dedak bahan ikutan berupa jerami dan dedak. Penggunaan kombinasi antara output padi sawah dengan sapi potong dengan pemanfaatan kotoran sapi sebagai pupuk organik untuk tanaman padi sawah dan limbah padi sawah berubah jerami dan dedak sebagai tambahan pakan ternak sapi potong merupakan 
ciri dari penerapan sistem integrasi ini (Fagi et al., 2004).

Melalui kombinas ini diharapkan mampu meningkatkan kesejahateraan masyarakat melalui penghematan biaya dan penambahan jumlah penerimaan dari dua sumber yakni hasil produksi padi dan hasil jual ternak. Oleh karena itu Pengembangan sistem integrasi padi-ternak (SIPT) merupakan salah satu pendekatan agribisnis yang penting untuk diterapkan karena melalui kombinasi kotoran sapi dan jerami padi akan mampu memberikan manfaat bagi petani (Mulyadi et al., 2013).

Potensi Luas lahan sawah dan jumlah ternak di Kecamatan Buke Kabupaten Konawe Selatan mencakup 637 hektar dan 3.534 ekor ternak sapi potong (BPS, 2016). Melalui potensi tersebut maka pengembangan sistem integrasi padi dan ternak sapi potong layak untuk dikembangkan dalam rangka untuk meningkatkan kesejahteraan petani. Pola sistem usahatani integrasi padi sawah dan ternak sapi potong telah tumbuh dan berkembang diperdesaan, salah satunya di Kecamatan Buke Kabupaten Konawe Selatan yang bertujuan untuk mengantisipasi resiko usaha dari kegagalan usahatani. Namun pola integrasi belum banyak diketahui oleh petani, karena umumnya pola usaha yang mereka terapkan adalah subsistem. Padahal dengan potensi lahan padi sawah dan ternak sapi yang dimiliki, maka petani seharusnya mampu untuk melakukan model pengelohan usahatani yang berbasis sistem integrasi padi ternak sapi potong. Karena itu penelitian ini difokuskan untuk mengetahui potensi dan kelayakan usaha sistem integrasi yang diterapkan oleh petani.

\section{METODE PENELITIAN}

Penelitian ini dilakukan di Desa Silea Jaya Kecamatan Buke Kabupaten Konawe Selatan. Penentuan lokasi penelitian dilakukan secara sengaja (purposive) dengan dasar bahwa di Kecamatan Buke terdapat petani yang menjalankan usaha sistem integrasi padi sawah dengan sapi potong. Populasi pada penelitian ini adalah semua petani yang menerapkan sistem integrasi padi ternakyaitu 25 orang. Karena jumlah populasinya tidak mencapai 100 orang, maka semua populasi dijadikan sampel penelitian.
Analisis data yang digunakan untuk menjawab permasalahan pertama yakni analisis deskriptif yakni untuk memberikan gambaran mengenai potensi pengembangan farming sistem integrasi padi ternak di daerah penelitian dan analisis kelayakan usahatani yakni analisis $R / C$ Ratio dan BEP.

Analisis $R / C$ Ratio di formulasikan menurut Soeharjo \& Patong (1984):

$$
R / C \text { Ratio }=\frac{\text { Total Revenue }(T R)}{\text { Total } \operatorname{cost}(T C)}
$$

Keterangan:

$\mathrm{TR}=$ Total Revenue $(\mathrm{Rp})$

$\mathrm{TC}=$ Total Cost $(\mathrm{Rp})$

Dengan kriteria :

- Jika R/C-Ratio > 1; layak secara ekonomis

- Jika R/C-Ratio = 1; impas

- Jika R/C-Ratio < 1; tidak layak secara ekonomis.

Analisis BEP di formulasikan menurut Suratiyah (2006):

$$
\begin{gathered}
\text { BEP volume produksi }=\frac{\text { Total } \text { Biaya } \text { Produksi }}{\text { Harga } \text { Jual }} \\
\text { BEP harga }=\frac{\text { Total Biaya } \text { Produksi }}{\text { Total } \text { Produksi }}
\end{gathered}
$$

\section{HASIL DAN PEMBAHASAN}

Sistem integrasi padi ternak dapat berjalan dengan baik jika didukung oleh potensi yang mencukupi baik dari ketersedian luas lahan dan jumlah ternak responden. Hal ini karena luas lahan padi sawah sangat menentukan besaran produksi padi sawah yang dihasilkan juga akan menentukan jumlah limbah padi sawah dalam bentuk jerami yang digunakan dalam sistem integrasi ini. Begitupula dengan jumlah ternak yang dimiliki, hal ini akan menentukan jumlah kotoran (feses) sapi potong yang dihasilkan untuk dipergunakan dalam sistem integrasi di lokasi penelitian ini.

\section{Potensi Luas Lahan Padi Sawah dan Kepemilikan Sapi Potong}

Luas lahan akan mempengaruhi produksi utama maupun limbah yang dihasilkan yang akan digunakan untuk pakan ternak sapi potong. Luas lahan sawah yang dimiliki petani responden mulai dari 0,5-1 ha. Data luas lahan dilokasi penelitian disajikan pada Tabel 1.

Tabel 1. Kepemilikan Luas Lahan dan Produktivitas Padi Sawah di Desa Silea Jaya Kecamatan Buke Kabupaten Konawe Selatan

\begin{tabular}{clccc}
\hline No & Luas Lahan & Rata - Rata Produktivitas $(\mathrm{Kg} / \mathrm{ha})$ & Jumlah (orang) & Persentase $(\%)$ \\
\hline 1. & 0,5 ha (sedang) & $3.976,4$ & 16 & 64 \\
2. & 1 ha (luas) & 7.677 & 9 & 36 \\
\hline & Jumlah & & 25 & 100 \\
\hline
\end{tabular}


Pada Tabel 1 diketahui bahwa luas lahan petani berkisar antara 0,5-1 ha. Luas lahan ini sangat menentukan produksi dari padi sawah yang dapat dimanfaatkan untuk pakan ternak. Berdasarkan hasil penelitian diketahui bahwa untuk luas lahan petani 0,5 ha rata-rata produktivitas yang dihasilkan adalah 3.976,4 $\mathrm{kg} / \mathrm{ha}$ sedangkan untuk lahan petani yang luasnya 1 ha rata-rata produktivitasnya $7,677 \mathrm{~kg} / \mathrm{ha}$. Semakin banyak produksi padi yang dihasilkan maka akan semakin besar pula ketersediaan jerami sebagai pakan ternak yang digunakan dalam usaha farming sistem ini. Hasil penelitian ini menunjukkan produksi padi yang lebih tinggi dari hasil penelitian Basuni et al. (2010) melaporkan sistem integrasi padi dengan sapi potong memberikan hasil produksi padi 5,34 ton/ha.

Sedangkan jumlah sapi potong menggambarkan banyaknya ternak yang dimiliki oleh masyarakat responden khususnya yang diintegrasikan dengan tanaman padi sawah. Jumlah sapi potong yang dimiliki dari tiap responden bervariasi, antara 1 sampai 6 ekor. Adapun jumlah kepemilikan ternak sapi potong pada petani sistem integrasi di Desa Sile Jaya Kecamatan Buke Kabupaten Konawe Selatan disajikan pada Tabel 2.

Berdasarkan Tabel 2 menunjukan bahwa jumlah sapi potong yang paling banyak dimiliki oleh responden pada skala 4-6 ekor sebanyak 17 orang (68\%) dan jumlah yang paling sedikit adalah pada skala 1-3 ekor (32\%), dengan rata rata umur sapi 3 tahun atau sudah tergolong dewasa. Hal ini menunjukkan bahwa skala kepemilikan sapi potong yang dimiliki responden masih tergolong kecil, hal ini karena responden hanya menjadikan usaha ternak sapi potong sebagai usaha sampingan. Jumlah ternak yang dimiliki ini sangat menentukan besaran output berupa kotoran sapi yang digunakan untuk pupuk organik dalam menunjang ketersediaan pupuk bagi tanaman padi sawah yang diusahakan. Semakin banyak ternak yang dimiliki maka semakin besar pula pupuk organik yang dapat digunakan untuk tanaman padi sawah.

\section{Potensi Limbah Padi Sawah dan Ternak Sapi Potong}

Potensi limbah padi sawah yang dimaksudkan dalam penelitian ini yaitu jerami yang bisa digunakan sebagai tambahan pakan ternak sedangkan limbah dari ternak sapi potong adalah fases (kotoran) ternak sapi yang bisa digunakan untuk pupuk organik untuk menunjang ketersedian kebutuhaan pupuk tanaman padi sawah. Uraian mengenai potensi jerami yang ada di Desa Silea Jaya disajikan pada Tabel 3.

Ketersediaan limbah padi dalam bentuk jerami kering dalam setiap kali produksi yaitu sekitar 4-5 ton jerami (berat kering per ha). Jumlah produksi ini sangat bervariasi karena dipenaruhi oleh lokasi, jenis varietas, cara, dan waktu pemotongan. Jerami padi yang dihasilkan ini dapat dimanfaatkan untuk mencukupi kebutuhan pakan sapi potong dewasa sebanyak 2-4 ekor setiap tahun. Maka, jika petani mampu melakukan panen padi sebanyak dua kali dalam setahun maka akan membantu dalam ketersediaan pakan sapi potong sebanyak 4-6 ekor.

Berdasarkan hasil penelitian yang dilakukan diketahui bahwa rata-rata produksi jerami segardi Desa Silea Jaya yaitu 34,4 ton/ha/tahun sedangkan untuk jerami kering adalah sebanyak 13,76 ton/ha/tahun. Menurut NRC (1984) bahwa kebutuhan bahan kering (BK) 1 Satuan ternak yaitu 2,28 ton/ha, sehingga jika responden memiliki rata-rata 4,08 ekor sapi dewasa, maka kebutuhan bahan kering jerami adalah 9,13 ton/ha/tahun.

Tabel 2. Jumlah kepemilikan sapi potong di Desa Silea Jaya Kecamatan Buke Kabupaten Konawe Selatan

\begin{tabular}{cccc}
\hline No. & JumlahTernak (ekor) & Jumlah (orang) & Persentase (\%) \\
\hline 1. & $1-3$ & 8 & 32 \\
2. & $4-6$ & 17 & 68 \\
\hline Jumlah & & 25 & 100 \\
\hline
\end{tabular}

Tabel 3. Potensi Rata-Rata Jerami dikawasan persawahan di Desa Silea Jaya Kecamatan Buke Kabupaten Konawe Selatan

\begin{tabular}{clrc}
\hline No. & \multicolumn{1}{c}{ Uraian } & Jumlah & Ket. \\
\hline 1. & Produksi Jerami Segar & 34,4 & ton/ha/tahun \\
2. & Jerami Kering & 13,76 & ton/ha/tahun \\
3. & Kebutuhan jerami untuk 1 ekor sapi dewasa BK 1 ST & 2,25 & ton/tahun \\
\hline
\end{tabular}


Oleh karena itu dengan potensi produksi BK Jerami yaitu sebesar 13,76 ton/ha/tahun, maka ketersediaan jerami untuk pakan ternak sangat mencukupi dengan selisih ketersediaan pakan ternak yakni 4,63 ton/ha/tahun.

Sedangkan limbah dari sapi potong untuk kebutuhan padi sawah adalah fases (kotoran) sapi oleh responden dapat digunakan sebagai pupuk organik padi sawah. Sehingga secara ekonomi penerapan sistem integrasi padi ternak ini mampu meminimalkan biaya produksi dalam pengelohan padi dan ternak responden. Setiap satu ekor sapi potong mampu menyediakan 1,5-2 ton pupuk organik, karena setiap harinya satu ekor sapi potong menghasilkan kotoran $8-10 \mathrm{~kg}$ per hari (Budiyanto, 2011). Sehingga berdasarkan hasil penelitian dilapangan pada Tabel 4 diketahui bahwa rata-rata kepemilikan ternak responden adalah 4 ekor maka produksi pupuk organik sebanyak 6 ton/tahun dengan mengambil produksi pupuk organik pertahunnya yakni 1,5 ton. Sedangkan kebutuhan pupuk organik yang digunakan pada usaha padi sawahnya hanya 2,1 ton/tahun. Sehingga ketersediaan pupuk organik dari ternak sapi yang miliki masih sangat mencukupi, dengan selisih ketersediaan pupuk organik 3,9 ton per tahun.

Maka dari itu dapat disimpulkan berdasarkan analisis potensi ouput yang dimiliki oleh responden pada usaha sistem integrasi padi ternak di lokasi penelitian sangat cocok untuk diterapkan secara berkelanjutan dalam rangka untuk peningkatan kesejahteraan petani. Bahkan agar mampu memberikan keuntungan yang maksimal maka petani dapat menambah pemeliharaan ternak yang dimiliki dan petani juga dapat mendatangkan sumber ekonomi baru bagi mereka yakni dengan menjual sisa fases (kotoran) sapi potong dan juga bisa diubah dalam bentuk biogas sehingga dapat bermanfaat bagi masyarakat setempat.

Analisis $R / C$ Ratio
Analisa imbangan antara total revenu
dengan total cost merupakan suatu pengujian
kelayakan pada suatu jenis usaha. Kriteria dari
hasil analisi R/C ratio adalah jika nilai $R / C$ Ratio
$>1$ maka usaha tersebut dikatakan untung dan
layak untuk dijalankan, karena besarny
penerimaan mampu menutupi biaya yan
dikeluarkan dalam usahatani, begitupun
sebaliknya penerimaan responden pada usah
farming system ini bersumber dari dua yakni
penerimaan dari sektor usahatani padi sawah dan
usaha pemeliharaan ternak sapi potong.
asil pupuk organik di Desa Silea Jaya Kecamatan Buke
Jumlah
(Per Tahun)
4
6

Tabel 5. Rata-rata penerimaan responden farming system ternak-padi sawah di Desa SIlea Jaya Kecamatan Buke Kabupaten Konawe Selatan

\begin{tabular}{clr}
\hline No. & Uraian & Jumlah (Rp/Tahun) \\
\hline 1. & Padi Sawah & \\
& Produksi (kg/tahun) & 5456,01 \\
& Harga (Rp/tahun) & 5.000 \\
& Penerimaan Padi Sawah (Rp/tahun) & 27.283 .000 \\
$2 . \quad$ Ternak & 2 \\
& Produksi (ekor/tahun) & 5.372 .000 \\
& Harga (Rp/tahun) & 7.536 .000 \\
\hline & Penerimaan Ternak (Rp/tahun) & 34.819 .000 \\
\hline
\end{tabular}


Tabel 6. Biaya rata-rata usahatani sistem integrasi ternak sapi potong-tanaman padi sawah di Desa Silea Jaya Kecamatan Buke Kabupaten Konawe Selatan

\begin{tabular}{clr}
\hline No. & Jenis Biaya & Jumlah (Rp/tahun) \\
\hline 1. & Padi Sawah & 120.329 \\
& Biaya Tetap : & 102.829 \\
& Biaya Penyusutan Peralatan & 17.500 \\
& Pajak Lahan & 5.631 .770 \\
& Biaya Variabel : & 225.200 \\
& Benih & 1.380 .800 \\
& Pupuk & 1.009 .555 \\
& Pestisida & 3.016 .215 \\
Tenaga Kerja & \\
Ternak & Biaya Tetap : & 246.491 \\
& Biaya Penyusutan Peralatan & 101.260 \\
Biaya Penyusutan Kandang & 145.231 \\
Biaya Variabel : & 622.067 \\
\hline Biaya Pakan Tambahan & 555.400 \\
\hline Biaya Vitamin dan Obat-Obatan & Jumlah Biaya Tetap (1+2) & 66.667 \\
\hline & Total Biaya (3+4) & 366.820 \\
\hline
\end{tabular}

Pada Tabel 5 diketahui bahwa penerimaan pelaku usaha farming system bersumber dari dua yakni padi sawah yakni sebesar Rp 27.283.000 per tahun dan dari ternak sebesar Rp 7.536.000 per tahun. Sehingga total penerimaannya sebesar Rp 34.819.000 per tahun. Nilai penerimaan sangat ditentukan dari harga dan jumlah produksi. Usaha ternak sapi potong hanya menghasilkan rata - rata Rp Rp 7.536.000,- per tahun hal ini karena jumlah produksi ternak yang mampu dijual oleh responden hanya 2 ekor dewasa saja. Jika penerimaan yang diterima oleh responden lebih besar dari biaya produksi, maka petani akan mendapatkan keuntungan dari jenis usahatan yang mereka lakukan.

Menurut Kusnadi \& Prawiradiputra (1993), integrasi ternak dan tanaman dapat meningkatkan keuntungan antara 14,9-129,4\%. Berdasarkan hasil penelitian bahwa terjadi peningkatan penerimaan responden, karena sumber penerimaan responden tidak hanya dari satu jenis usaha tetapi bersumber dari dua jenis usaha sekaligus. Sedangkan biaya total dalam usaha farming system ini terdiri dari biaya tetap dan biaya variabel. Biaya tetap yang dikeluarkan dalam usaha farming system ini adalah biaya penyusutan peralatan, penyusutan kandang dan pajak lahan. Biaya variabel diantaranya adalah benih, pupuk, pestisida, tenaga kerja, pakan tambahan, obat-obatan dan vitamin. Sehingga hasil analisis $R / C$ Ratio pada Tabel 7 yaitu sebesar 5,26 .

Tabel 7. Besar R/C Ratio usaha farming system ternak padi sawah di Desa Silea Jaya Kecamatan Buke Kabupaten Konawe Selatan

\begin{tabular}{clr}
\hline No & \multicolumn{1}{c}{ Uraian } & \multicolumn{1}{c}{ Nilai } \\
\hline 1 & $\begin{array}{l}\text { Total Penerimaan } \\
\text { (Rp/tahun) }\end{array}$ & 34.819 .000 \\
2 & Total Biaya (Rp/tahun) & 6.620 .657 \\
3 & R/C Ratio $(\%)$ & 5,26 \\
\hline
\end{tabular}

Berdasarkan Tabel 7 diketahui bahwa $R / C$ Ratio usaha farming system yakni 5,26 ( $R / C$ Ratio $>1$ ). Secara ekonomis, usaha farming system ternak-padi sawah layak untuk di usahakan atau dikembangkan. Nilai $R / C$ Ratio sebesar 5,26 berarti bahwa pengorbanan (biaya produksi) sebesar Rp 1,00 maka akan mendapatkan penerimaan sebesar Rp 5,26, dengan pendapatan yang akan diperoleh sebesar Rp 4,26. Maka berdasarkan hasil analisis $R / C$ Ratio maka dapat dsimpulkan bahwa usaha farming system di Desa Silea Jaya layak secara ekonomi untuk dikembangkan. Hal ini sesuai dengan hasil pene- 
Tabel 8. Break event point usaha farming system ternak padi sawah di Desa Silea Jaya Kecamatan Buke Kabuparen Konawe Selatan

\begin{tabular}{clcc}
\hline \multirow{2}{*}{ No. } & Uraian & \multicolumn{2}{c}{ Jumlah } \\
\cline { 3 - 4 } & & Padi Sawah & Ternak \\
\hline 1 & Volume Produksi (kg/tahun); (Ekor/Tahun) & 5456,01 & 2 \\
3 & Harga Jual (Rp) & 5.000 & 5.372 .000 \\
& Biaya Total (Rp/tahun) & 5.752 .099 & 868.558 \\
\hline 4 & BEP Volume Produksi (kg); (ekor) & $1.150,41$ & 0,2 \\
\hline 5 & BEP Harga Jual (Rp) & $1.054,27$ & 432.279 \\
\hline
\end{tabular}

litian yang dilakukan oleh Usman et al. (2017) dan Tumewu et al. (2014) bahwa usaha farming system memberikan kelayakan dengan nilai $R / C$ Ratio $>1$. Oleh karena itu melalui penerapan teknologi sistem integrasi padi dengan sapi potong ini, mampu memberikan perbaikan kondisi ekonomi petani melalui penghematan biaya produksi dan peningkatan penerimaan, sebagaimana yang diungkap dalam penelitian Yuliani (2014) bahwa dengan teknologi integrasi padi-ternak dapat memperbaiki tambahan pendapatan bagi petani dalam kondisi sinergisme dalam pemanfaatan input usahatani dari sumber tersedia secara optimal.

\section{Break Event Point (BEP)}

Analisis $B E P$ digunakan untuk menghitung besarnya penerimaan dan produksi yang harus dicapai agar petani memperoleh keuntungan, serta harga jual yang menentukan apakah petani mendapat keuntungan dari total biaya produksi yang telah dikeluarkan. Analisis BEP pada penelitian ini melihat pada dua aspek yakni BEP volume produksi dan BEP harga jual dalam rupiah. Berdasarkan hasil analisis Tabel 8 diketahui bahwa untuk usaha padi sawah nilai BEP nya yaitu jika produksi yang dihasilkan ratarata $1.150,41 \mathrm{~kg}$ dengan harga jual $\mathrm{Rp} 1.054,27$ sedangkan nilai $B E P$ untuk usaha sapi potong ratarata 0,2 ekor dengan nilai Rp. 432.279. Hal ini berarti bahwa usahatani padi sawah baru akan memperoleh keuntungan apabila petani berproduksi lebih dari 1.150,41 dengan harga jual di atas Rp 1.054,27. Sedangkan usaha sapi potong baru akan memperoleh keuntungan apabila peternak memelihara ternak sapi potong lebih dari 0,2 ekor dengan harga jual di atas Rp 432.279.

\section{KESIMPULAN}

Berdasarkan hasil penelitian dan pembahasan dapat disimpulkan bahwa usaha sistem integrasi padi ternak di Desa Silea Jaya
Kecamatan Buke Kabupaten Konawe Selatan cukup memiliki potensi hal ini dilihat dari ketersediaan luas lahan padi sawah, jumlah ternak, limbah padi sawah, dan sapi potong. Kelayakan usaha sistem integrasi padi dengan sapi potong layak untuk dijalankan hal ini terlihat dari hasil analisis $R / C$ Ratio yaitu 5,26 (R/C Ratio $>1)$ dan analisis BEP untuk padi sawah yakni $1.150,41 \mathrm{Kg}$ dengan harga jual Rp 1.054,27. Sedangkan ternak sapi potong yakni 0,2 ekor dengan nilai $\mathrm{Rp}$. 432.279

\section{DAFTAR PUSTAKA}

Basuni, R., Muladno, C. Kusmana, \& Suryahadi. 2010. Model sistem integrasi padi-sapi potong di lahan sawah. Iptek Tanaman Pangan 5(1):31-48.

Budiyanto, M.A.K. 2011. Tipologi pendayagunaan kotoran sapi dalam upaya mendukung pertanian organik di Desa Sumbersari Kecamatan Poncokusumo Kabupaten Malang. Jurnal Gamma 7(1):42-49

[BPS] Badan Pusat Statistisk. 2016. Kabupaten Konawe Selatan dalam Angka 2015. Badan Statistik Kabupaten Konawe Selatan. Andoolo.

Fagi, A.M., I.G. Ismail, \& S. Kartaatmadja. 2004. Evaluasi pendahuluan kelembagaan usahatani tanaman-ternak di beberapa kabupaten di Jawa Tengah dan Jawa Timur. Prosiding Lokakarya Sistem dan Kelembagaan Usahatani Tanaman Ternak. Badan Litbang Pertanian. Jakarta.

Kusnadi, U. \& B.R. Prawiradiputra. 1993. Produktivitas Ternak Domba dalam Sistem Usahatani Konservasi Lahan Kering di DAS Citanduy. Risalah Lokakarya Penelitian dan Pengembangan Sistem Usahatani Konservasi di DAS Citanduy, 
Linggarjati, 9-11 Agustus 1988. Hlm 205293.

Mulyadi A., Wihardjaka, \& P. Setyanto. 2013. Pengelolaan biogas dari integrasi tanaman pangan dan ternak sapi pada lahan sawah tadah hujan. Prosiding Expose dan Seminar Nasional Inovasi Pertanian Ramah Lingkungan. 19-21 Juni 2013. Balai Besar Pengkajian dan Pengembangan Teknologi Pertanian, Bogor. Makassar 19-21 Juni 2013. Hlm. 685-693.

NRC. 1984. Nutrient Requiremant of Domestic. National Academy of Washington DC.

Soeharjo, A. \& D. Patong. 1984. Sendi-sendi Pokok Usahatani. Universitas Hasanuddin. Ujung Pandang.

Suratiyah, 2006. Ilmu Usahatani. Penebar Swadaya. Jakarta.

Tumewu, J.M., V.V.J. Panelewen, \& A.D.P. Mirah. 2014. Analisis usaha tani terpadu sapi potong dan padi sawah kelompok tani "keong mas" Kecamatan Sangkub, Kabupaten Bolaang Mongondow Utara (Studi Kasus). Jurnal Zootek 34(2):1-9.

Usman, S. Tirajoh, Y. Baliadi, \& A.W. Rauf. 2017. Kelayakan Usaha Tani Padi dan Sapi Potong Mendukung Pengembang-an Sistem Integrasi Tanaman-Ternak di Kabupaten Merauke, Papua. Prosiding Seminar Nasional Teknologi Peternakan dan Veteriner. Pusat Penelitian dan Pengembangan Peternakan, Bogor. Bogor, 8-9 Agustus 2017. Hlm 191-197.

Yuliani, D. 2014. Sistem integrasi padi ternak untuk mewujudkan kedaulatan pangan. Jurnal Agroteknologi 4(2):15-2 